\title{
Lumen
}

Selected Proceedings from the Canadian Society for Eighteenth-Century Studies

\section{Anna Maria Falconbridge and the Sierra Leone Colony: 'A Female Traveller in Conflict'}

\section{Moira Ferguson}

Volume 16, 1997

Freedom and Boundaries

Émancipation et frontières

URI : https://id.erudit.org/iderudit/1012436ar

DOI : https://doi.org/10.7202/1012436ar

Aller au sommaire du numéro

Éditeur(s)

Canadian Society for Eighteenth-Century Studies / Société canadienne d'étude du dix-huitième siècle

ISSN

1209-3696 (imprimé)

1927-8284 (numérique)

Découvrir la revue

Citer cet article

Ferguson, M. (1997). Anna Maria Falconbridge and the Sierra Leone Colony: 'A Female Traveller in Conflict'. Lumen, 16, 1-24.

https://doi.org/10.7202/1012436ar 


\section{Anna Maria Falconbridge and the Sierra Leone Colony: 'A Female Traveller in Conflict'}

A newcomer to the colonial enterprise in West Africa, Anna Maria Falconbridge recorded her experiences during two visits to Sierra Leone in the late eighteenth century. She was the first English-speaking woman on the West Coast of Africa to articulate a response to the colonial settlement. Her text, entitled Two Voyages to Sierra Leone During the Years 1791-2-3, in a Series of Letters, ${ }^{1}$ was the 'first independent published report on the colony'. It provides an account of her experiences with her husband Alexander Falconbridge during his time as administrator in the Sierra Leone company, the commercial enterprise that followed the first attempted self-governing colony on the African West Coast, and includes the Falconbridges' second term, which coincided with the arrival of the black Nova Scotian Loyalist community. The text concludes with her return to London, disagreements with the Sierra Leone Company, and correspondence by two black Loyalist settlers, Cato Perkins and Isaac Anderson. ${ }^{2}$ The fourteen letters which constitute Two Voyages vividly inscribe the ambivalences of Anna Maria Falconbridge's position with reference to colonization, slavery, and the intersections of race, culture, and gender.

Seven years prior to the publication of Two Voyages, in 1787, several hundred liberated slaves and some white prostitutes sailed for Sierra Leone, after the abolitionist Granville Sharp devised a plan for a slavefree, self-governing British settlement there. ${ }^{3}$ After they sailed, a third of the convoy died, while the settlement that the remaining community built was burned down after an altercation with a neighbouring chief. ${ }^{4}$ At that point, some well-connected abolitionists assumed responsibility for the project, reorganized the old settlement as a commercial enterprise, and named it the Sierra Leone Company. According to the charter, they would introduce the 'Blessings of Industry and Civilization' into Africa, 'long detained in barbarism' (Spitzer; Wilson, Clarkson 84).

Falconbridge's abolitionist husband assumed an administrative role in the colony, and she accompanied him there in 1688, after their elope- 
ment had caused a scandal in her hometown of Bristol. Alexander Falconbridge had become ardently opposed to slavery in 1687, after his experiences as a surgeon on the slave ships crossing the notorious Middle Passage; he had published an exposé of his experiences earlier in 1688 (Account of the Slave Trade). The first dinner with other white residents in Sierra Leone was a tense affair, with arguments about the slave trade frequently erupting. Consequently, Falconbridge refused his wife's request that they sleep comfortably on shore at the home of slave traders; for him - but not, evidently, for her - any complicity in slavery was repellent. He decided that they should camp on the supply ship, the Lapwing, which she compared to a hog trough (23).

Conceive yourself pent up in a floating cage, without room either to walk about, stand erect, or even to lay at length; exposed to the inclemency of the weather, having your eyes and ears ... offended by acts of indecency, and language too horrible to relate - add to this a complication of filth, the stench from which was continually assailing your nose, and then you will have a faint notion of the Lapwing Cutter. (24)

Falconbridge's annoyance here is gender-, culture-, and class-specific, embodying white female European ideals and expectations. Yet it also curiously parallels her husband's powerful descriptions of the filth and crowding aboard the slave ships. Her account asserts cultural dominance while at the same time it suggests the potential blurring of settler/slave distinctions; it vividly epitomizes the ambivalence and instability of her own stance. She begs the captain to have the Lapwing washed down. Scrubbing the ship, while it may indict slavery by implication, also restores a form of control and matches ideal white middleclass feminine behaviour. Scouring the cabin with vinegar emblematizes not only her harsh and sour surroundings but also the anger she feels at being stuck in this situation. Ironically, then, while her 'housekeeping' may embody a metaphoric cleansing of the slave trade, in itself it springs from her own need for white, middle-class standards of comfort. Acid applied to metonymized slave ships can be read as symbolically corroding the plantocratic system they support. But within a day, notwithstanding differences between her husband and the slavetraders, Anna Maria finagles a tour on shore in the company of the latter.

Ambivalence was inherent to the Falconbridges' position in the colony. Although Alexander Falconbridge strenuously opposed the slave trade, as chief British negotiator he nonetheless participated in a massive territorial swindle. Anna Maria was present during the first day of the two-week long debate over land; in her account she is both overtly 
condescending towards the Naimbana and boldly direct in representing his comments during the negotiations. She tells us

He was dressed in a purple embroidered coat, white satin waistcoat and breeches, thread stockings, and his left side emblazoned with a flaming star; his legs to be sure were harliquined, by a number of holes in his stockings, through which his black skin appeared. (34)

But she is afraid to mend holes in his stockings since drawing blood on a king is punishable by death.

As a bribe to secure land and coastline for the British, Alexander Falconbridge offers rum, wine, cheese, and a gold-laced hat to the king, while arguing that the old contract signed by the king and a British representative three years earlier remains valid. As Britain's spokesman, Falconbridge claims that Englishmen would never renege on a contract and would hold 'in detestation every person so disposed' (36). He stresses his disdain for 'obtaining wealth,' while Anna Maria spotlights the extensiveness of the West African territory at stake and the extent to which the Africans are being infantilized:

Here Falconbridge, interrupting the King, said - 'The King of the English will not blame your people, but load yourself with the stigma; it is King Naimbana who is ostensible to King George - and I hope King, you will not fall out with your good friend.' This being explained by Mr. Secretary Elliotte, his Majesty was some moments silent - when clasping Falconbridge in his arms, told him - 'I believe you and King George are my good friends - do not fear, have a good heart, I will do as much as I can for you. (39)

Later in the negotiations, Falconbridge charges that 'the wretches were only bamboozling him' (59). Nonetheless, here Anna Maria boldly represents the alternate point of view, the Naimbana's opinion that 'every white man [is] a rogue'(37).

By now, the Falconbridges are privy to the alternate narrative about the burning of the original settlement, the story of flagrant baiting of the Africans by British individuals. But their knowledge of this narrative of the colonized cannot dissolve official allegiances. Their presence as bureaucrats induces them to support the British colonial position wholeheartedly, despite any personal reservations they might have. Their position, in a sense, necessitates cultural distortion.

After that first day of negotiations, Anna Maria Falconbridge feigns sickness and attends no further meetings. Instead she enjoys excursions with a French slaver named Captain Rennieu (Holland 31), whose occupation she never mentions. The captain's slave-trading negotiations 
within and around the community are a resounding textual silence in her letters. The fact that her husband is contracting for slave-free territory along the slave coastline while she spends time in the company of slave traders goes unnoted. Also unnoted is any link between the peoples' public ritual to ward off evil (i.e. slavery) and evidence of slave-trading around town:

In different parts of the town I observed some rags stuck on poles, at the foot of each were placed - perhaps a rusty cutlass, some pieces of broken glass, and a pewter bason, containing a liquid of some sort; these are called Gree Grees, and considered as antidotes against the Devil's vengeance. I was thoughtlessly offering to examine one of them, when Mr. Elliotte requested me to desist, or I should give offence, they being held in a very sacred point of view. (40-41)

In conventional ethnographic commentary, she alludes to cultural practices and leaves it at that.

While visiting Bunce island, home of a French slave-trading station, she unexpectedly glimpses a group of slaves:

Judge then what my astonishment and feelings were, at the sight of between two and three hundred wretched victims, chained and parcelled out in circles, just satisfying the cravings of nature from a trough of rice placed in the centre of each circle. Offended modesty rebuked me with a blush for not hurrying my eyes from such disgusting scenes; but ... I could not withdraw myself for several minutes - while I remarked some whose hair was withering with age, reluctantly tasting their food - and others thoughtless from youth, greedily devouring all before them; be assured I avoided the prospects from this side of the house ever after. (32-33)

Her distraught response resembles her husband's in his anti-slavery tract when he describes the slave ship as 'beyond the human imagination ... It was a slaughter house [covered with] blood and mucus'(25). Yet Anna Maria's response is informed by white middle-class gendered expectations, those of a proper English woman. She quickly recovers and assumes a detached attitude.

Her choice of this incident to highlight the presence of slavery is complex. First, Two Voyages was published in 1794, when Britain was already at war with France. Hence her description of this atrocity might also contain a francophobic dimension. The rhetoric of French grossness is also, as Peter Hulme argues in a different context, a 'ruse of concealment' about British slavery (1). Second, as a woman, Anna Maria Falconbridge is supposed to forego a masculinist gaze; she is not supposed to look and possess what is seen in the same way. She does not avert her 
gaze; but the spectacle has power over her rather than the reverse. She employs, not an 'objectivist discovery rhetoric,' but one that is 'resolutely dialogic, seeking out rather than defying local knowledge,' a colonial discourse that violates gender codes (Pratt 102-107). And the distance she assumes is a colonial complement to the more active male gaze that does not - as she does - flinch and withdraw.

Her representation of slavery is further complicated by a sense of the parallels between their situation and her own. In her account she views Africans as inferior: she scoffs that they speak 'broken English'; she labels indigenous people as lazy (83); she describes the racial separation of burial grounds without comment (83), remarking, also without comment, that 'deaths are not frequent' there (84) (see also 88, and Alates 112). Yet the woeful sight of slaves enhances her sense of personal entrapment, both her physical entrapment in the ship itself, as seen the imagery of her earlier description, and, with a double irony, what she perceives as the social and political entrapment resulting from her husband's strong abolitionist views.

Much of the blurring of distinction between herself and the black slaves arises from her position as a woman; she strives to reassert that distinction through upholding white European models of femininity. Exporting prescibed notions of womanhood from Britain to Africa, Falconbridge both accepts and denies the cultural definition of femininity. Although given to bold, unconventional acts - her elopement signifies as much, as does her hasty remarriage - she strives to appear lady-like. After noticing how people stare at her elaborate outfits, she utilizes dress to uphold European standards, even to construct a notion of gendered whiteness. ${ }^{5}$ She strains to construct a visible little England that upholds sartorial custom, while attempting to erase the potential parallels between herself and the Africans. The stunned attention her costumes receive is similar to the attention she herself trains on the Naimbana's attire; but in that case, she returns the gaze that was trained on her own clothes, turning the king into her object of ridicule. His high rank notwithstanding, he is the colonized, who is stared upon by the colonizer. Similarly, when the king mentions that no other woman has ever sat down to eat with him, she assumes he is granting her a privilege rather than noting her inferior status as a woman. Cancelling the king's comment arbitrarily, she acts as if British cultural status supersedes gender.

Additionally, she tries to talk the Naimbana's daughter, Clara, into wearing the cumbersome western attire deemed 'feminine,' since scanty dress speaks preconceived ideas about allegedly unsophisticated Africans. ${ }^{6}$ Instead, Falconbridge wants English womanhood to assert its universal form (Anderson 23). By mimicking her, Clara will replicate that 
form and stress the colonizer's authority. But Clara wisely declines, whereupon Falconbridge petulantly dismisses her.

Predictably, the situation of other white females - a remnant of the original settlers - disturbs Falconbridge the most; she condemns their involuntary expatration as white prostitutes who will become breeders. When she comes upon seven of them who are diseased and unkempt, she undertakes to clean them up; she wants them to copy her own impeccable grooming, just as she wanted Clara and the Lapwing to reflect her sense of propriety. Her anxiety is the more intense as these women blur the racial/cultural distinction inscribed by clothing:

I should never have supposed they were born white; add to this, almost naked from head to foot ... they seemed insensible to shame, or the wretchedness of their situation themselves; I begged they would get washed, and gave them what cloaths I could conveniently spare. (64)

White gendered authority and a veiled patriotism are at stake; the description is also informed by an unsentimentalized sense of solidarity with her white sisters. Privileging whiteness, exonerating this septet as European women enduring hard times, she reads their condition as a sign of their exploitation. The British government exploits prostitutes, she implies, as yet another commodity, like slave or palm oil. She tenders a description of their abduction, repeated to her by one of the group:

The women [who came to Sierre Leone] were mostly of that description of persons who walk the streets of London; and support themselves by the earnings of prostitution; that men were employed to collect and conduct them to Wapping, where they were intoxicated with liquor, then inveigled on board of ship, and married to Black men, whom they have never seen before; that the morning after she was married, she really did not remember a syllable of what had happened over night, and when informed, was obliged to inquire who was her husband? After this, to the time of their sailing, they were amused and bouyed up by a prodigality of fair promises, and great expectations which awaited them in the country they were going to. (65)

Falconbridge finds this treatment - their sexual exploitation, their reduction to a category usually reserved for black women - unacceptable, since she reserves a status of difference for white women. When sluttishness becomes a sliding signifier attached to white women, things have gone too far. Ironically, English national identity here meshes with ravished white female identity, ${ }^{7}$ threatening distinctions between colonizer and colonized. The parallel between white female commodification - in this instance, their virtual exportation - and the slave trade 
here and elsewhere in the British colonial world serves to intensify Falconbridge's anxiety.

Anna Maria Falconbridge's challenges to the modus operandi of the London administrators highlight the extent to which the colonial situation itself threatened to obscure colonial distinctions. From the outset, the type of supplies sent to the colony had incurred her wrath. Instead of food, administrators had sent out tools used by blacksmiths and plantation owners - of scant use in the colony - as well as numerous toy knives and scissors.

There was not a thing on board, but salt beef, so hard, we were obliged to chop it with an axe, and some mouldy, rotten biscuits; however, so great was my hunger, that I could not help satisfying it with some of this beef and bread, uncouth as it was. (58)

Here, in terms of diet, Anna Maria Falconbridge might also see parallels between her condition and that of the slaves she pictured earlier. Shortly after, she mocks the weapons that were exported from England to arm settlers: they could not be fired because their carriages were missing (68). With each objection, Falconbridge shifts position, reinforcing the plurality of colonial practices; her authority as a white English lady differs from that of a white English gentleman. She confirms their contesting terrains, the often contradictory axes of power among the English themselves, as a new corporate institution strove to emerge in West Africa.

Falconbridge thus refuses to lock herself into a self-perpetuating, traditional colonial-gender grid. Her personal situation undermines the binary opposition even further. In her own view, the abolition movement itself has trapped her and locked her up, as it trapped the unfortunate white female settlers. Her husband's fervour marginalizes them socially and politically, limiting her freedom to enjoy the privileges of her European identity, and rendering her position even closer to that of the slaves.

The Falconbridges left Sierra Leone for London - for good, they thought - in June 1791, to report to the Company Directors. The Naimbana's son (known popularly as Prince Naimbana, and sometimes as John Frederick) accompanied them at the Naimbana'a request. Intent on intitating a new commercial venture in the colony and smoothing relations with the indigenous population, the Directors coaxed the couple to return. ${ }^{8}$ A battery of promises won over a reluctant Anna Maria: first, her husband Alexander would probably be governor of Sierra Leone as well as a commercial agent; second, she would be well compensated if he died. She comments, "Though all their rhetoric could not 
persuade me to revisit Africa, their noble generous actions have effected it' (223).

In addition to Falconbridge's appointment, the directors hired one hundred and nineteen white Company officials, who arrived in Sierra Leone in February 1792 (Holland 18; Asiegbu 12). They also arranged for a black community of twelve hundred men and women living in Nova Scotia to be relocated there. These three groups - the Falconbridges themselves, the company officials, and the sizable black convoy - were due to arrive in Sierra Leone at roughly the same time. This wave of black immigrants permanently altered the composition of the colony. Resourceful and religious, the large black community was know familiarly as the Nova Scotians or the Loyalists, because they had fought on the British side in the American revolutionary war in order to emancipate themselves. ${ }^{9}$ As compensation, they had been expatriated to Canada from the United States, and promised land which they never received.

Anna Maria Falconbridge's representation of the Loyalists' troubled repatriation in Africa is crisscrossed with ambiguities; she utilizes their narrative of injustices to express her own disapproval of the Company administration, while remaining silent as to their claims for racial equality. She tells the story of John Clarkson, brother of the famous abolitionist Thomas Clarkson, being dispatched to Nova Scotia to finesse the repatriation of the Black Loyalists to Sierra Leone. They contracted with Clarkson not only to accept land there to compensate for broken promises by the British government about land in Nova Scotia, but also to 'form a colony' (Peterson 29). In a reverse reiteration of the middle passage, one hundred of them died en route from Canada to West Africa. After he arrived, Clarkson was appointed governor of the colony, news that dismayed Alexander Falconbridge, who had been half-promised the position (Wilson, Clarkson 81). Anna Maria Falconbridge antagonistically pronounced the repatriation plan

A premature, hair-brained, and ill-digested scheme, to think of sending such a number of people all at once, to a rude, barbarous, and unhealthy country, before they were certain of possessing an acre of land; and I very much fear will terminate in disappointment, if not disgrace to the authors; though at the same time, I am persuaded the motives spring from minds unsullied with evil meaning. (125)

The present inexperienced administrators, she fears, will bring about 'anarchy and chagrin' (141). The disappointed reactions of the pious Black Loyalists to the discriminatory conditions they faced in the colony matched Falconbridge's own growing disapproval of the governing body (201; see also Lyotard 19; Clarke 33-34; Sanneh 68-71). The Nova 
Scotians quickly discerned the exclusionary tactics which were brought to bear: thrown in jail on trivial charges, castigated as 'black rascals,' from the beginning their demands were either ignored or trivialized. ${ }^{10}$

But for John Clarkson's term of office as governor - Anna Maria was one of his supporters - she downplays the grievances of black settlers. She cannot easily confront the implications of the 'figure of the diaspora' returned (Young 17). Thomas Peters, for example, the Nova Scotian leader who challenged Clarkson's administration, took literally the idea that 'civil, military, personal, and commercial rights and duties of Blacks and Whites shall be the same. ${ }^{11}$ Apparently on reasonable terms with neighbouring tribal Africans, but coming to realize that the British had double-crossed them once again, the Nova Scotians faced off against white bureaucrats as they reenacted their earlier battles during the American War of Independence; autonomy and economic survival were their goals (Fyfe, Our Children 11). Falconbridge merely alludes to the Nova Scotians' letters and petitions about freedom during this period (Wilson, Clarkson 113; Charles Jones in Fyfe, Our Children 79-102). Her description of life in the colony contributes to the 'epistemic violence that effaces the colonial subject,' representing the ideological struggle there, almost, as one between diverse white communities (see Donaldson). Falconbridge's silent chronicle about the Black Loyalists and their demands marks her complex location - her desire for gendered authority on the one hand, her opposition to abolitionist bureacrats on the other. In some sense she writes 'not the history of the country which he [the colonizer] plunders, but the history of his own nation' (Wilson 84; Asiegbu 17).

Recognizing that their hard work benefitted the British Directors of the Sierra Leone Company, the Black Loyalists still cast their lot with the colony. Men cleared the brush while women washed and cooked. Eventually they built an encampment into which the original white settlers resettled (Harris, Tradition). Their industry notwithstanding, the Nova Scotians were forbidden to hold most administrative posts. The blandishments about equal treatment were palpably a myth (Fanon 40). Falconbridge records the settlers' outburst:

'Why are not our country allotments of land surveyed? Why are not all the Company's promises to us fulfilled? We have a high regard and respect for $\mathrm{Mr}$. Clarkson, and firmly believe he would not have left us, without seeing every promise he made performed; if gentlemen here had not given him the strongest assurances they should be complied with immediately.' In answer, they were told, 'that it was not uncommon for Mr. Clarkson to make prodigal and extraordinary promises without thinking of them afterwards, that the great advantages 
he held out to them in Nova Scotia he was in no shape authorised by the Sierra Leone Company to make. (205-206)

Alexander Falconbridge died in December 1793 after a tough struggle to initiate trade relations; three weeks later Anna Maria Falconbridge happily married Isaac Dubois. ${ }^{12}$ Her decision not to mention the name of her new spouse in Two Voyages or indicate beyond suffestive hints that she was remarrying points to her apprehensions about claiming sexual freedom. The evangelical British/colonial ruling class might have targeted her precipitous behaviour much as the sexual practices of slaves were targeted. Not long after the marriage, the Company dismissed Clarkson, who had returned to London. Falconbridge and Dubois shared the settlers' disappointment with the news. Discord intensified. The newly-married couple left Sierra Leone for good in August 1793, their differences with the colonial bureaucracy no longer reconcilable. ${ }^{13}$

Meanwhile, Europe was at war. Hence, Anna Maria Falconbridge makes only a casual passing remark about the fact that the Naimbana's son had died in July 1793, en route to Sierra Leone to become the Naimbana (Holland 39). West African internal affairs no longer claim her attention. She begins to reposition herself at a great distance from the colony, both physically and politically.

Back in London, Anna Maria demanded that the Director of the Company, Henry Thornton, fulfil financial promises that he made when the Falconbridges agreed to return to the colony for a second time. Thornton refused to comply (Clarkson papers, vol. 3). Perhaps her refusal to assume the role of widow for longer than three weeks had rendered her morally suspect (cf. Poovey 3-47). At any rate, fractures in the seemingly united white colonial front were now evident to those in the know.

During the time that Falconbridge was petitioning Henry Thornton. Cato Perkins and Isaac Anderson had also arrived in London, on behalf of the Nova Scotian community, to present a petition signed by thirtyone black settlers. Perkins and Anderson expressed their displeasure at broken promises and demanded fair and equal treatment. Where colonizers were concerned, they had learned, no a priori guarantees existed. As deeply religious men - Perkins was an ordained pastor - they could not be dismissed as hot-headed pagans. As part of a contingent of former slaves rebelling for the third time, Perkins and Anderson circulated an oppositional discourse of emancipation; they pointed out why distrusting the company officials made sense. They showed Anna Maria Falconbridge a copy of their letter to the Directors; she then transcibed it in her text, in her own phrase, 'word for word': 
We have been so often deceived by white people, that we are jealous when they make any promises, and uneasily wait till we see what they will come to. . . The manner [in which] you have treated us, has been just the same as if we were Slaves, come to tell our masters, of the cruelties and severe behaviour of an Overseer. (264-65)

Where earlier in her text she made only limited reference to the existence and the struggle of the black settlers in Sierra Leone, now Falconbridge textually foregrounds Perkins and Anderson as ideological allies (or weapons) in her struggle against Thornton. ${ }^{14}$

This opening up of liminal space, this foregrounding of black speech and self-determination, intensifies Falconbridge's textual ironies. Her location is persistently traversed by contradictions. By giving voice to former slaves who are the Directors' opponents, Falconbridge associates the abolitionist ideology of colonizers with duplicity and injustice. Hence she makes good her prefatory warning to readers that her account will be 'uncompromising' and filled with 'unwelcome truth.' Earlier quarrels with her abolitionist husband quietly resurface. And more has happened in the interim to complicate the scenario. In letter ten of Two Voyages, Falconbridge mentions that the return voyage to London had changed her view of slavery; abolitionists, she claims, exaggerated the negative conditions aboard slave ships. Thus Falconbridge aids the former slaves and gives them voice in her text, while arguing for her own private rights and edging towards a pro-slavery stance. Her fluctuating response constitutes a radical rupture in the text.

Though they returned to Sierra Leone empty-handed, Perkins and Anderson accentuated the ambiguities of power through their sturdy actions. Their intrepidity signified that the empire could not easily be solidified or codified. They exemplified the dynamic possibilities of even the colonizing narrative. From Africa to North America and back again as representatives of their community, Perkins and Anderson inscribed and reinscribed themselves in the culture of resistance. These involuntary yet subversive nomad-hybrids used Anna Maria Falconbridge's account, in Edward Said's words, 'to assert their own identity and the existence of their own history' (xii). They offered an alternate social experience and marked it as integral to the colonial quest. Falconbridge's text records this testimony and their feisty counter-refusal to be orientalized, to be placated. Yet, ironically, these black petitioners for equality served as Falconbridge's occasion for a not-so-veiled denunciation of the abolitionist-colonial administrators at home and in Sierra Leone, and thus for her putative pro-slavery stance. 
Two Voyages is written in a plethora of forms that includes reminiscences, a pro- and anti-slavery critique, a commentary on sexual politics, a manners and customs chronicle, a historical dedication and record, and a manifesto of burgeoning nationalism. Petitions, speeches, conversations, second-hand commentary, gossip, anecdote, omissions, and personal opinion are also included. With tribulations and high points juxtaposed, Falconbridge's polyphony of texts doubles as the literature of survival and the literature of conquest while she pointedly advances a political agenda of her own. An apparatus of power that affirms dominant ideology and advocates going slow on slavery, her text is transformative and heteroglossic. In Wilson Harris's words, her text constitutes a 'trail of silent things' (Tradition)

Even the chronology of Two Voyages remains a textual ambivalence. We will never know if she sent those letters and if she did, if the sender returned them to her. Falconbridge's whereabouts after the period covered by the text remain a mystery. Nothing is known of Thornton's ultimate decision, but we suspect contrivance. This indeterminacy about chronology and order destabilizes the text.

To add to the destabilizing effect, Falconbridge opens Two Voyages with a complimentary address to the people of Bristol, a notorious slave-trading port; most of them would be repelled by an anti-slavery narrative. Bristol becomes a code word for pro-slavery supporters and plantocrats, with Anna Maria Falconbridge a prodigal daughter returning to the fold. Earlier, she had eloped with Alexander Falconbridge, who was now dead. While in West Africa, she married a man from the former American colonies, whose parents seem to have owned plantations. Written after her husband's death and her own remarriage, the address to Bristolians, then, functions as a reconciliation device: the apostrophe serves to placate members of a community who matter to her, but who were repelled by her former behaviour. The attack on Henry Thornton consolidates this alliance with Bristolians. So does the appendix that she added between the first and second editions: it consists of a second letter to Thornton in which she refers to herself as an injured woman and to Thornton, in calculatedly Christian terms, as an unrepentant malefactor.

Nonetheless, when Two Voyages was published, Anna Maria still used Alexander Falconbridge's name, a name that was inextricably associated with abolition. Perhaps Dubois was too French for a francophobic English readership in 1794. Perhaps she thought the familiarity of Falconbridge's name would attach more authority to her text and sell more books. In any case, she appropriates the last name of a famous abolitionist to undermine abolition. By adding a panegyric to her hometown after she writes Two Voyages and after she has severed ties with the abolitionist 
colonial administration, she absolves herself from complicity in her first husband's beliefs. Using a fractured chronology, she can present herself as someone sympathetic to a proslavery argument, implicitly excusing her elopement with an ardently abolitionist husband on the grounds of youth and naiveté, and, in her complicitous address, asking her former community for forgiveness. She has already done penance - she hints - by combating abolitionist forces.

Another factor complicating Falconbridge's colonialism is her assertively feminine perspective, which challenges masculinist colonial discourse, whether abolitionist or plantocratic. We know from Falconbridge's preface that she was anxious to distinguish her account from another contemporary account of Sierra Leone by Lieutenant John Matthews. ${ }^{15}$ She will avoid the facts - she avows - that Matthews addresses. Falconbridge explicitly retains the gendered gaze that must eschew the 'objective' description of discovery favoured by male travellers. While underscoring her diffidence in emulating Matthews - she eschews being a mimic or a bore, she explains - she claims a different kind of discourse as her own. Falconbridge overtly and unsentimentally personalizes her account, asserts strong opinions, dramatizes ideological oppositions, undertakes character assassinations and affirmations, and rarely shies from subjects (such as prostitutes) scarcely deemed appropriate for a woman writer to discuss. She creates a gendered colonial discourse for female travellers that claims both class and race privilege, inscribing a critique of masculinist organization and thinking. Her discourse complements that of the male colonizer, but she insistently separates and authorizes herself on the basis of gender.

In her conciliatory opening address and the self-justifying appendix, Anna Maria Falconbridge exemplifies the problems that a pioneer faces. As a female colonizer she has to create new conventions, construct an acceptable authenticity. Nonetheless, she refuses to be constrained by the customary discourses of femininity and faces some 'unfeminine' sights and experiences head on. At the same time, since so many experiences and events are illegible to her, her text is always unstable, never fixed, despite her hardy eurocentric efforts to represent a female gaze. Special conditions induce her to produce a different kind of text.

Falconbridge's insistence on female colonial power being taken seriously, right down to the propriety of dress, would also have excited debate. Refusing to succumb to the fixed stance of widowhood yet displaying herself as a proper English lady in the tropics, she asserts her position as an economically self-sustaining worker to whom the Directors were accountable. Highlighting gender as a mark of difference, she bestows a new legitimacy on female colonial narratives. Her epistolary 
chronicle challenges travel accounts by white male counterparts that exoticize women or erase them as subjects. ${ }^{16}$

Hence her gendered travel narrative enhances the articulation of imperial meaning-making. Through female cultural inscription that privileges dress, hygiene, the sick, hasty marriage, hastier remarriage, and efforts to darn holes in the king's stockings, Falconbridge extends and complicates the colonial trajectory. She delineates novel boundaries within which she can exercise female authority. Abolitionist Thornton declines serious negotiations with her on the basis of her suspect views, most likely, but surely as an evangelical male he also takes umbrage at the permission Falconbridge grants other women to enunciate a controversial public discourse. The fact that she inflects the text with a clandestine seduction that speaks sexual desire less than a month after her husband's death clinches that separation between herself and Thornton: national decision-makers like Thornton cherished the spread of such landmark British values as morality and piety. Originally Anna Maria Falconbridge might have seemed a worthy import and model, a woman who could redeem a region thought to be sunk in barbarism or vexed by rancour. Not to put too fine a point on it, Thornton might well have encoded her exceptional behaviour as part of the very ethos that the evangelicals sought to clean up in so-called 'uncivilized' Africa. Through aggressive action, she had declined the role of a 'feminine' British patriot in abolitionist terms (Poovey 32).

The discontinuities in Falconbridge's colonial stance, embedded in the initial speech and appendix of Two Voyages, persist through the events covered by the text. Falconbridge socializes with slave-traders. At the same time, she is friends with Governor John Clarkson, who helped bring the Nova Scotia black community to Sierra Leone. Her representation of her relations with Thomas Peters, who was frequently a leader in fighting for black settlers' demands, shifts from minimal voicing to more overt expression; her representation of the Loyalists' case is similarly two-edged, as she utilises their demands for equal treatment to support her own critique of the abolitionist administration and thus to support her own pro-slavery proclivities.

Two Voyages thus reveals ambivalent relations to the Nova Scotians, to African peoples in Sierra Leone, and to the Company directors back home. In condemning the company's treatment of the Nova Scotians, she ultimately demurs about the enactment / possibility / practicability of a slave-free community. Moreover, her evolving plantocratic stance only seems to clash with her concern for the settlers; on a personal level, she identifies with the denial of their rights because she felt similarly denied by the same company directors. Hence, at one level, Falcon- 
bridge's account reads as an exposé of colonial mismanagement and ill-advised efforts to suppress black resistance, by administrators who promoted abolition but facilitated profit. The Nova Scotians themselves are caught in the twisting paths of the emancipatory trajectory, the much-touted civilizing mission, and Falconbridge's own agenda.

Her own Eurocentric motivation aside, Falconbridge's account is nonetheless highly significant in giving both voice and specificity to the generalized colonial Other. Her foregrounding of black settlers' petitions in both Sierra Leone and London sounds their demands into the void and exposes the veto of silence that the British government had tried unsuccessfully to impose. By centrestaging the Nova Scotians' fight for autonomy, Falconbridge counters the contentions that the relocated African community is fractious without reason. She explodes old equations about unvoiced otherness and ignorance, unmasking false representations of British colonialism in Africa. She constructs a platform from which Nova Scotians and Africans can make pronouncements - albeit mediated through her own unstable perspective - as 'newly empowered voices asking for their narratives to be heard' (Said $x x, x i)$. In the process, Falconbridge denounces the double-voiced Sierra Leone Company which opposes slavery yet denies black settlers' demands: she returns a discourse about slaves to the original geographical source of its institutional practice. More - in her descriptions of such diverse Africans as Pa Bunkie (or Bongee), his palaver man, the Naimbana, and 'King Tom,' she dissolves received notions about totalized black communities. ${ }^{17}$

Notwithstanding these polyvocal elements in her account, however, Falconbridge's narrative is yet another aspect of overseas predation, the colonial mythology of origins early on in West Africa. ${ }^{18}$ Paradoxically, Falconbridge's publicizing of black dissent specifically advances the territorial enterprise. Nova Scotians might be free people acting appropriately, but they also welcome Falconbridge's assistance when the Sierra Leone Company wears them down in London with a series of flat refusals and a waiting game. Her aid to Perkins and Anderson affirms something akin to plantocratic philanthropy. Ironically, Falconbridge's narrative of colonial 'legitimation' in West Africa echoes that of Thornton and his allies in London, regarding the same black communities, a doubled colonizing enterprise. Her underwriting of proslaveryites through her appropriation of the black community's demands for autonomy links slave trading to a strong national identity. Falconbridge and Thornton battle over ideological representations of Africa, but they are still silently united in configuring the continent and the people as the Other of civilized Europe. Politically they slide easily into each other, 
using the black Loyalists differently, but still as a negative commodity in either case. Consequently, Falconbridge ends up representing herself as a mediator and saviour whose avowal of a gradualist position on slavery - the Eurocentric idea that Africans must be slowly introduced to freedom - enables her to justify pro-slavery proclivities (Lyotard 22-23). ${ }^{19}$

Moreover, the charity she extends in London to Isaac Anderson and Cato Perkins obscures this transformation from an abolitionist who risked social ostracism to marry an anti-slavery activist to someone who remarks on the acceptable conditions she observes on board a slave ship in the Middle Passage. Since neither morality nor education can be found in unhappy Africa, she claims, the slave trade must be beneficial. Her standard of judgment is simple. She wants everyone to have freedom to know its value, a catch clause that covers old ideas about allegedly ignorant Africans. In the end, she reverted unapologetically to a way of thinking shared by family and friends in Bristol. Her dedication to the inhabitants of Bristol, a major pro-slavery port and her hometown, couples the importance of natal town and love - systematically denied to slaves - with her new attraction to a modified, pro-slavery perspective.

Falconbridge's ideological shift (or reversion) is most transparent, however, in the change in diction on the title pages of subsequent editions of Two Voyages: the original title page in 1794 becomes a plug for the plantocracy in the 1802 edition. The original title page reads as follows: Two Voyages to Sierra Leone During the Years 1791-2-3, in a Series of Letters, by Anna Maria Falconbridge To which is added, A Letter from the Author to Henry Thornton, Esq. M. P. and Chairman of the Court of Directors of the Sierra Leone Company. The second title page recasts her politic, advocating the gradualist viewpoint on slavery favoured by plantocrats. It reads as follows: Narrative of Two Voyages to the River Sierra Leone, During the Years 1791-2-3, performed by A. M. Falconbridge. With a Succinct account of the Distresses and proceedings of that Settlement: a description of the Manner, Diversions, Arts, Commerce, Cultivation, Custom, Punishments, Ec. And Every interesting Particular relating to the Sierra Leone Company also The present State of the Slave Trade in the West Indies, and the improbability of its total Abolition.

The expansion of the original title page without any alteration to the text itself suggests that Anna Maria Falconbridge wants readers to recast her discourse. Her second title page - she ventures - will provide an ideological gloss. Read it this way, she urges, and read it differently. She thus clarifies, rather than mystifies, her political evolution during her visits to the colony, implicitly stressing her distance from the indigenous people and from the Nova Scotian community. 
The second title page also confirms that Two Voyages had become even if it did not set out to be - a brief for European expansionist ideology. Once again, the voyage is a critical colonial topos. Concurrently, her shift signifies that antiphonic definitions of nationalism are vying for approval. In the process, Falconbridge softens predation, rehearsing her colonial identity and Britain's territorial entitlement.

Who speaks and writes for whom, then, is a crucial site of contestation. In giving voice to black settlers and silencing their narratives, Falconbridge highlights the fact that collective illiteracy from a eurocentric point of view constitutes self-erasure. Put another way, the question of signature characterizes the civilizing mission and the representation of indigenous people. Literacy is central to the ideological sweepstakes. When Africans who do not speak English put an X on documents, that $\mathrm{X}$ becomes a subject of merriment in the House of Commons. (As cases in point, the Naimbana, Cato Perkins, and Isaac Anderson all render their signatures as $\mathrm{X}$.) In the eyes of a European reading public, illiteracy indicates inferiority; it revives the issue of Britons authorizing themselves, throughout the history of the slave trade, to name Africans. Illiteracy justifies naming; literacy permits (is) naming. The black settlers' making an $\mathrm{X}$ on a document detracts from Falconbridge's ascription of intellectual power to them. Viewed eurocentrically, collective ignorance unites Africans with Nova Scotians. ${ }^{20}$ Through self-representation, moreover, Falconbridge offers new roles and new hope to planters and pro-slaveryites: she softens the public revulsion against them, in the struggle for different formulations of empire. Yet her very ambivalence marks a hegemonic stance; relative inequities matter because she perceives important differences between Nova Scotians and herself. Additionally, she claims that this emerging nation of combative communities has been founded on unworkable principles, and she promotes the circular argument that if Africa were not actually as barbaric as Europeans allege, slavery would no longer be necessary.

In cobbling together these contrary viewpoints, Falconbridge reinforces the pragmatic difficulty of the double-talking civilizing mission, spotlighting the internal divisions among differently motivated colonizers. Yet the various traumas she hints at are not cut and dried. The narrative of colonialism cannot be neatly partitioned between colonized and colonizer (Suleri).

Two Voyages, then, is integral to imperial implantation. Drilling the British public in a gradualist politic that represents England to itself, Falconbridge articulates diverse black self-representations. Her oscillation between an evolving pro-slavery vantage point and an economic self-interest is inextricably bound up with a suspect (and standard) 
philanthropic project. She proclaims the partiality and hence the unauthenticity of the overall picture, representing Sierra Leone only as she expected or wanted it to be. She constructs and confirms a certain national identity, a vocabulary of rights that supports both slavery and colonialism (Hall 207). Furthermore, the popular epistolary form of her narrative authorizes a certain handbook view of Sierra Leone: people back home can imagine the settlement through her eyes; they can identify with her goals, and hence learn acceptable parameters for a patriotic response to overseas rule.

Regardless of her altercation with the Company over political direction in Africa, the lives of the indigenous and repatriated Africans that Anna Maria Falconbridge chronicled in Two Voyages were built on the European imaginary. All she did was give the colonial project a new twist, a novel context for reconstituting the cultural geography of Sierra Leone and hence Englishness.

MOIRA FERGUSON

University of Nebraska

Notes

Another version of this essay appears in Cultural Readings of Imperialism: Edward Said and the Gravity of History, edited by Keith Ansell-Pearson, Benita Parry, and Judith Squires (London: Lawrence and Wishart, 1997).

1 All references are to the second edition. Regarding Anna Maria Falconbridge's life, extensive archival research in Bristol and Somerset has yielded only scant information about her. Her marriage is recorded in the Easton in Gordano marriage register as follows: '1788 Oct. 16 Alexander FALCONBRIDGE Bachelor \& Maria HORWOOD spinster, both of this parish, by banns.' There are FALCONBRIDGE and HORWOOD entries for baptism in the same parish register. The Bristol Wills Index and the index of Wills proved in the prerogative court of Canterbury (Index, vol. 1) reveal no entries of immediate relevance.

2 For the documents of Cato Perkins and Isaac Anderson, see Fyfe, Our Children.

3 For information on Sierra Leone, see Fyfe, History 35; Stride and Ifka; Alie; Peterson 26-27. Note also that the persistent plans to colonize the land were tied to abolitionist agitation from Britain. Preparatory to the St. George's Bay Company receiving its new charter, the noted abolitionist Thomas Clarkson, on tour around England in 1791, had informed audiences that about two thousand acres of sugar cane would be grown in Sierra Leone with free, not enslaved, labour. This crop would cut the price of West Indian sugar in half. Eventually Britain would be trading with free Africans in Sierra Leone (Curtin 106). 
4 'King Tom,' sub-chief of the Koya Temne kingdom, who had ceded ten miles of coastline without the approval of the Naimbana. The Naimbana is not a king, nor is 'King Tom.' 'Naimbana' is the title and rank of the paramount sub-chief of the Koya Temne, which was one of several important Temne kingdoms in what is now coastal and central Sierra Leone (Alie 14-16). In 1775, when the paramount ruler or O'bai died, the current Naimbana, whose name is not otherwise known and who lived at thee settlement at Robana on the south shore of the Sierra Leone River, became regent of the kingdom, a position he held until his death in 1793. The new O'bai, Bai Farma II, who came to power in 1794, was not as sympathetic as the old Naimbana had been to the presence of the colonists on the peninsula (Ijagbemi 16, 47; Fyfe, History 54). For the negotiations of 'King Tom' and 'King Naimbana' with the British, see Ijagbemi 21-36. The British expeditions to Sierra Leone in the 1780 s were by no means the first. See, for example, A collection of Voyages and Travels, vol. 5. This volume includes 'An Account of the Rise and Progress of Our Trade to Africa, preceding the year 1697' (5. 665-668). The Royal Africa Company report speaks of the progress of trade after 1697 and the need to maintain 600 officers; note also that the Company maintained - among many others - the James Fort in the Gambia and the Sherbro Fort in North Guinea.

5 For a compelling analysis of the construction of white femininity, see Ware xvii, 163 , and passim. See also Vivien Jones's useful anthology.

6 Mills 178; see also Strobel 39, and passim.

7 For discussions of Englishness at this time, in addition to Anderson, see Colley, Newman, and Bhabha.

8 Report. . of the Sierra Leone Company. . . See also Meacham 104-105; Asiegbu 212. The Company Report in 1791 reads as follows:

It must appear from the general account already given, that the Directors are endeavoring in the outset rather to lay the foundation of happiness in Africa, and of future prosperity to the Company, then to grasp at any premature advantages. They trust, however, that they are not indulging too sanguine a prospect in looking forward to considerable and growing profits, directly resulting from and intimately connected with the general and increasing prosperity of the country, subject to their jurisdiction.

Early in 1791, Henry Thornton further reiterates the purpose of the Company:

The Sierra Leone Company, established by the British Parliament do hereby declare, that they will send out goods from England and take all kinds of African produce in exchange; that they will not deal in slaves themselves, nor allow of any slave trade on their ground...

They wish always to keep peace, and will make no war, unless they are first attacked; but they will suffer no one to be ill-treated on their ground, nor to be seized and carried off into slavery; but will themselves punish their own people for any crimes fairly proved to have been committed by them.

Black and white settlers will all be equally governed, and will have their persons and property secured, according to the laws of Great Britain.

Schools of reading, writing, and accounts will be set up by the company, who will be ready to receive and instruct the children of such natives as shall be willing to put them under their care.

Anna Maria Falconbridge circulates an alternate set of colonizers' ideas about Sierra Leone. For this phenomenon in an earlier period, see Frantz. 
9 Holland 18. For information about Thomas Peters, see Wilson, Blacks 108-113, 212-213, 248-253; see also C. H. Fyfe, 'Thomas Peters.'

10 Wilson, Clarkson 80-87. The following information about John Clarkson's administration comes from this text.

11 Wilson, Clarkson 93. William Hogarth's satirical mid-century portraits of mimicking black servants suggest the divisions in British society about the role black men and women should play, and the power they should have (see Dabydeen). Peters gave the lie to any chance that British roles could easily be transposed into Sierra Leone.

12 Correspondence between Dubois and Clarkson indicates that the Reverend Melville Horne married Anna Maria Falconbridge and Isaac Dubois on January 7th, 1793. The public wedding celebration took place on January 21st, 1793 (Clarkson papers).

13 Dubois tells Clarkson in a letter he writes on January 13, 1793, that Dawes, the new governor of Sierra Leone, 'never called on me since I was married - would Mr. Clarkson have done so? How Opposite!!!' Dubois goes on to complain, ten days later, of workers being forced to attend service: 'is it not a pity that religion should be a cloak to vice and idleness.' In February, he explains to Clarkson that he was not permitted to finish building his houses. Dubois later denounces the clergyman Horne's efforts to convert 'Grown Up Natives' as a 'fruitless scheme': 'If Africa should ever become a civilized and enlightened country, I hazard an opinion that this will but in a trifling degree be brought about by Preaching to the Grown Up Natives.' Dubois also describes earlier conversations at dinner with the slavetrading captain Rennieu, who gave Dubois and Anna Maria Falconbridge news about the Naimbana's succession. Dubois' account seems conflicted: he supports the abolitionist Clarkson, yet renders Eurocentric condescending views of Africa and Africans, and does not try to hide his friendship with a notorious slaver.

On a related subject, Dubois tells Clarkson about 'the dismissal of $\mathrm{Mr}$. Horwood, Mrs. Dubois's brother, without assigning any reason whatever for so doing' (May 1st, 1793). Dubois had threatened to report this to Clarkson, but Dawes replied that 'they were not accountable to Mr. Clarkson for their conduct but to the directors of the Sierra Leone Company only' (Clarkson papers, vol. 3).

14 Note here that the British administrators defend their policy by pronouncing Dubois a liar and claiming that he doctored the documentation (Wilson, Blacks 295, and passim). For further information on Dubois, see letters from Dubois to Clarkson, February 15th and October 26th, 1793 (Clarkson papers, vol. 3).

15 Falconbridge's fluid, explicitly political positions distinguish her narrative from the traditional univocal format of British travellers' tales such as that exemplified in Matthews' account.

16 Sara Mills discusses the role of femininity in women's travel narrative and their divergence from 'standard Orientalist description' (94-107). See also Poovey 28-29. Pratt specifically discusses Falconbridge's multiple viewpoints and how her perspective differs from the 'rhetorics of anti-conquest' (103-107).

17 The Naimbana is the darling of the British bureaucrats. (See note 4, above, for proper use of African titles.) 'Pa Bunkie'(or Bongee) is also a title. He was a sub-chief under 'King Tom.' Although seemingly unaware of the implications of her account, Falconbridge gives voice to African critiques of European practices 
through quotations from these persons. Decrying imperialism - perhaps the first African to be voiced so explicitly - Pa Bunkie's palaver man tells him

And what makes them thus suddenly over generous to you? - Because they think your services will soon be requisite for them. Do not you know white men well enough, to be convinced they never give away their money without expecting it returned many fold? - Cannot you see the drift of this profuse, unlooked for, and unasked for present? Let me warn you against taking it for be assured, however disinterested or friendly they appear at this moment, they are aiming at some selfish purposes, and although they may not discover what their wishes are immediately - before twelve moons more you will know them. - Bunkie replied, I know they want something, nevertheless I'll take the dash - it rests me, whether to comply with any request they make or not. I shall not consider the present, by any means binding on me. (199)

Noteworthy, too, is Pa Bunkie's rejection of the wise advice. At this point, the text becomes transformative because, in this episode, it indicates a new relation of power. Anti-white sentiment is implied before but never spoken.

18 For a brilliant account of the seemingly contrary colonial vantage points, see Pratt, especially 58-85.

19 Like Christians, Falconbridge claims to care about both 'the life of the spirit and/or the emancipation of humanity' (Lyotard 19).

20 While Falconbridge may not be homogenizing the African community as a universal subject, she shows scant sympathy for any African community. As a result, her discourse is grounded in a European view of the Other. Moreover, it is not only those who mark their names with an $\mathrm{X}$ who are singled out as objects of ridicule; there is a corresponding silence concerning and elision of those Africans who are literate enough to write English, let alone those who read and write Arabic. This appears to have been the case with Pa Bunkie and Dick Robin (later 'Prince Tom'), both of whom signed Taylor's Treaty with their title or name.

\section{Works Cited}

Alates, Syed Hussein. The Myth of the Lazy Native: A Study of the Image of the Malays, Filipinos, and Javanese from the Sixteenth to the Twentieth Century and Its Function in the Ideology of Colonial Capitalism. London: Frank Cass, 1977.

Alie, Joe A. D. A New History of Sierra Leone. London: Macmillan, 1990.

Anderson, Benedict. Imagined Communities: Reflections on the Origin and Spread of Nationalism. London: Verso, 1983.

Anonymous. A collection of Voyages and Travels, Some now first printed from original manuscripts, others now first published in English. With a general preface, Giving an Account of the Progresses of Trade and Navigation, from its first Beginning. Vol. 5. London: T. Osborne, 1752.

Asiegbu, U. Johnson. Slavery and the Politics of Liberation 1787-1861: A Study of Liberated Africans in Emigration and British Anti-Slavery Policy. London: Longman, 1969. 
Bhabha, Homi K. Nation and Narration. London: Routledge, 1990.

Bristol Wills Index 1770-1858.

Clarke, Peter B. West Africa and Christianity. London: Edward Arnold, 1986.

Clarkson papers. BL Add. MSS 41: 263404 E. 17

Colley, Linda. Britons: Forging the Nation 1707-1837. New Haven: Yale UP, 1992.

Curtin, Philip D. The Image of Africa: British Ideas and Action, 1780-1850. Madison: U of Wisconsin P, 1964.

Dabydeen, David. Hogarth's Blacks: Images of Blacks in Eighteenth-Century English Art. Denmark: Dangaroo P, 1985.

Donaldson, Laura E. Decolonizing Feminisms: Race, Gender, and Empire-Building. Chapel Hill: U of North Carolina P, 1992.

Easton in Gordano, Somerset, Marriage register 1788.

Easton in Gordano, Somerset, Baptisms register 1760-1772, 1788-1792.

Falconbridge, Alexander. An Account of the Slave Trade on the Coast of Africa. London: J. Phillips, 1788.

Falconbridge, Anna Maria. Two Voyages from Sierra Leone During the Years 1791-2-3, in a Series of Letters, by Anna Maria Falconbridge To which is added, A Letter from the Author to Henry Thornton. Esq. M.P. and Chairman of the Court of Directors of the Sierra Leone Company. The Second Edition. London, 1794.

Fanon, Frantz. The Wretched of the Earth. Trans. Constance Farrington. Harmondsworth: Penguin, 1967.

Frantz, R. W. The English Traveller and the Movement of Ideas 1660-1732. Lincoln: U of Nebraska P, 1934.

Fyfe, Christopher. A History of Sierra Leone. Oxford: Oxford UP, 1962.

ed. 'Our Children Free and Happy:' Letters from Black Settlers in Africa in the 1790s. Edinburgh: Edinburgh UP, 1991.

Fyfe, C. H. "Thomas Peters: History and Legend." Sierra Leone Studies n.s. 1 (December 1953): 4-13.

Green, Martin. Dreams of Adventure, Deeds of Empire. London: Routledge and Kegan Paul, 1980.

Hall, Catherine. White, Male, and Middle-Class: Explorations of Feminism and History. Cambridge: Polity P, 1992.

Harris, Wilson. Tradition, the Writer and Society: Critical Essays. London and Port of Spain: New Beacon Publications, 1967.

Holland, Margaret Jean Trevelyan, Viscountess Knutsford. Life and Letters of Zachary Macaulay. London: Edward Arnold.

Hulme, Peter. Colonial Encounters: Europe and the Native Caribbean 1492-1792. New York: Routledge, 1986.

Ijagbemi, Adeleye. Naimbana of Sierra Leone. African Historical Biographies. London: Heinemann, 1976. 
Index to the Wills Proved in the Prerogative Court of Canterbury 1750-1800. Ed. Anthony of Camp. 6 vols. London Society of Geneaologists, 1976.

Jones, Charles. "Some Grammatical Characteristics of the Sierra Leone Letters." Appendix. Fyfe, Our Children 79-102.

Jones, Vivien, ed. Women in the Eighteenth Century: Constructions of Femininity. London: Routledge, 1990.

Lyotard, Jean François. The Postmodern Condition: A Report on Knowledge. Minneapolis: U of Minnesota P, 1991.

Matthews, John. A Voyage to The River Sierra Leone, on The Coast of Africa; Containing an Account of the Trade and Production of the Country, And of the Civil and Religious Customs and Manners of the People: In a Series of Letters To a Friend in England. By John Matthews, Lieutenant in the Royal Navy; During His Residence in that Country In the Years 1785, 1786, and 1787, With An Additional Letter On the Subject of The African Slave Trade. Also, A Chart of Part of the Coast of Africa, from Cape St. Ann, to the River Rionoonas; with A View of the Island of Bananas. London: B. White and son, J. Sewell, 1788.

Meacham, Standish. Henry Thornton of Clapham, 1760-1815. Cambridge, MA: Harvard UP, 1964.

Mills, Sara. Discourses of Difference: An Analysis of Women's Travel Writing and Colonialism. London: Routledge, 1991.

Newman, Gerald. The Rise of English Nationalism: A Cultural History 1740-1830. New York: St. Martin's, 1987.

Peterson, John. Province of Freedom: A History of Sierra Leone 1787-1870. Evanston, IL: Northwestern UP, 1969.

Poovey, Mary. The Proper Lady and the Woman Writer: Ideology as Style in the Works of Mary Wollstonecraft, Mary Shelley, and Jane Austen. Chicago: U of Chicago P, 1984.

Pratt, Mary Louise. Imperial Eyes: Travel, Writing and Transculturation. London: Routledge, 1992.

Said, Edward. Culture and Imperialism. New York: Alfred Knopf, 1991.

Sanneh, Lamen. West African Christianity: The Religious Impact.

Spitzer, Leo. The Creoles of Sierra Leone: Responses to Colonialism, 1870-1945. Ile-Ife, Nigeria: $\mathrm{U}$ of Ife $\mathrm{P}, 1975$.

Stride, G. T. and Caroline Ifka. Peoples and Empires of West Africa. West Africa in History 1000-1800. Sunbury-on-Thames: Nelson, 1971.

Strobel, Margaret. European Women and the Second British Empire. Bloomington: Indiana UP, 1991.

Substance of the Report Delivered by the Court of Directors of the Sierra Leone Company to the General Court of Proprietors. London, 1791.

Suleri, Sara. The Rhetoric of English India. Chicago: U of Chicago P, 1992.

Ware, Vron. Beyond the Pale: White Women, Racism, and History. London: Verso, 1992. 


\section{Moira Ferguson}

Wilson, Ellen Gibson. The Loyal Blacks. New York: G. P. Putnam, 1976.

John Clarkson and the African Adventure. London: Macmillan, 1980.

Young, Robert. White Mythologies: Writing History and the West. New York: Routledge, 1990. 